\title{
Insights from the Brazilian and Mexican Aerospace Innovation System: National or Regional System
}

\author{
Alejandro Romero ${ }^{1, *} \&$ Dalton Garcia Borges de Souza ${ }^{2}$ \\ ${ }^{1}$ Department of Management and Technology, School of Management, University of Quebec in Montreal, Montreal, \\ Canada \\ ${ }^{2}$ Universidade Federal de Itajuba, Itajuba, Brazil \\ *Correspondence: Department of Management and Technology, School of Management, University of Quebec in \\ Montreal, 320 St. Catherine East, Montréal, Québec, H2X 1L7, Canada. Tel: 1-514-987-3000, ext. 2840. E-mail: \\ romero-torres.alejandro@uqam.ca
}

Received: September 16, 2016

Accepted: October 9, 2016

Online Published: October 21, 2016

doi:10.5430/mos.v3n4p36

URL: http://dx.doi.org/10.5430/mos.v3n4p36

\begin{abstract}
Although national systems of innovation is not a theory, but rather a focusing tool or a combination of concepts relying on established theory models, this paper explores the aerospace industry as a system of innovation and highlights the structure, the institutions forming this system and the mechanisms employed to promote innovation. This paper will use a conceptual approach to introduce two models of national systems of innovation: the aerospace industry cluster in Brazil and in Mexico. We realized a content review of documents published in the Internet by the public and private sector to describe Brazilian and Mexican innovation systems. Additionally, we developed a database of different actors involved in these innovation systems and their related characteristics: region, size, mission, objectives, partners, customers and projects. We analyzed the above information to better characterize the Brazilian and Mexican innovation systems. Even if both countries are two emergent economies, there are major differences between them. Brazil has developed an innovation system focus on creating innovation. Whereas, Mexican innovation system is divided into two types of networks: international capital organizations that invest in innovation and national capital organizations that invest in manufacturing. Both innovation system experience coordination failures since their actors have weak collaboration links.
\end{abstract}

Keywords: innovation system; aerospace industry; developing countries; governance; economic growth

\section{Introduction and Purpose}

In recent decades, governments of the World has a great interest in achieving competitive advantages in their economies that allow them to achieve sustainable and comparable or greater economic growth than that of their peers. One of the ways used more often to achieve these competitive advantages is the development of a better ability to innovate - to generate new products, designs, processes, services, methods or organizations or to increase value to existing (Von Hippel, 2005). A country with major strengths in the area of innovation will be better able to increase productivity, not only by the direct effect generated by the innovation, but above all because it will be better prepared to face the uncertainties generated by the current environment of global competition and better prepared to adapt itself to changing conditions in its environment (Nelson et al., 2007).

In the innovation filed, researchers have increased their interest in explaining the nature of innovation and technological change and its impacts in economic growth and social development. In particular, attention has focused on analyzing the various functions and interactions of different actors that contribute decisively to the innovation process (Aboites and Crown, 2011). Although national systems of innovation is not a theory, but rather a focusing tool or a combination of concepts relying on established theory models, this paper explores the aerospace industry as a system of innovation and highlights the structure and the institutions forming this national system, as well as mechanisms employed to support innovation. This paper will use a conceptual approach to introduce two models of national systems of innovation: the aerospace industry cluster in Brazil and in Mexico. 
The objective of this paper is to assess the aerospace innovation system in Brazil and Mexico to identify convergences and divergences between two developing economies. In the following section, we first present our literature review including a discussion of innovation systems in developing countries. Then, we defined the structure and mechanism of an innovation system. In the next section, we describe our methodology and present our two business cases. Then, we present our main results. And finally, in the discussion and conclusion sections, we state some implications as well as directions for future research.

\section{Literature Review}

\subsection{Innovation System}

The concept of innovation system began in the mid-eighties of the 20th century and was broadened in the following decades by neo-Schumpeterian authors, such as Lundvall (2002), Nelson (2004), among others. These authors defined innovation system as the coordinated set of heterogeneous actors that interact for the generation, dissemination and application of new economically useful knowledge (Carayannis and Campbell, 2012). They argued that in today's globalized scenario, competitiveness is the ability to generate an interconnected system that performs or assist to generate or disseminate knowledge and innovation. Furthermore, learning and knowledge generated by these interactions between the various actors are fundamental to the process of economic and technological development (Doloreux and Parto, 2005).

The generic approach innovation system adds the national, sectorial, regional and local dimensions. These dimensions complement each other: the sectorial, regional and local systems are part of the national system of countries. Spurred by globalization national systems of countries are also interconnected, all being part of a larger system of global dimensions. Based on the literature, a national innovation system is defined as a set of policies, agents (organizations, companies and consumers) and their respective relationships, which has the ability to facilitate creation, dissemination and application of new knowledge and innovations in a particular country, region or economic sector. It is believed that this set of interacting and with others in the global, national, regional and local context agents can drive innovation activities. This definition is valid for all dimensions of the innovation system: supranational, national, regional. Sanchez-Hernandez and co-authors (2010) identify the following characteristics common innovation systems:

i) Adopt a "holistic", "historical" and "evolutionary" perspective as they try to include economic, social, political, organizational and cultural factors and cover all types of innovation (products and processes, incremental and radical organizational and technological, institutional and services) and consider incorporating interdisciplinary knowledge of various sciences;

ii) Emphasize the complex relationships and interdependence among agents that feed each other based on co-operation and mutual trust governed by laws, rules and formal and informal rules (North, 2008);

iii) Consider the positive aspect between innovation and economic growth and social development.

The concept of innovation system since it emerged, has received great attention by the academy demonstrated in the number of studies on this topic. However, there is an academic debate on strengthening the concept of national innovation system. Uyarra (2010) and other authors highlight some weaknesses and criticize the approach of the national innovation system for its "conceptual ambiguity", because of the diversity of the concept attributed by different authors. Among these criticisms, Hernandez and co-authors (2010) quoted: i) there remains some confusion for central concepts of national innovation system; ii) the limits of these systems are specified; iii) does not exist between the authors agree on what constitutes a national innovation system; iv) no levels are identified, involved hierarchy, functions and activities of national innovation systems. Recognizing these criticisms, Campbell and Guttel (2005) argue that the aim of innovation system theory is to develop a frame of reference that is useful in the analysis and offers a better understanding of the dynamics of innovation. Therefore, the points that some consider as a disadvantage, these authors consider as positive by offering a flexible and useful analytical reference for a better understanding of innovation processes and development of a given territory.

To strengthen Innovation System theory, Leydesdorff and Etzkowitz (cited by Carayannis and Campbell, 2012) proposed a new model of representation of the interactions between these agents, called "Triple Helix". This model was created to describe complex interactions and ventures that arise within and outside the various actors that cooperate each other in the process of innovation and diffusion of knowledge. This model seeks to represent as their helices (in a spiral shape) the different roles assumed by each agent in these complex networks of interactions and 
co-operation between them (Leydesdorff, 2013). Each helix represents a player in the innovation system (see figure 1):

i) Private organizations are located in the centre of a strong network of interactions, determining the speed and direction of the process of innovation and technological change, operating as agent for the local/regional development (Sbragia et al., 2004);

ii) Universities and research centres collaborate with companies to produce knowledge through research and development (R\&D) (Sbragia et al., 2004), transfer knowledge through the formation of human capital, and through the publication of their results, and diffuse useful knowledge for solving problems with society (Hoppe, 2005).

iii) Government entities aim to encourage and support activities between companies and universities establishing rules and standards, buying technology products and services and funding research and innovation projects (Belussi et al., 2010). Therefore, government leads that knowledge generated by universities and applied by organization could contribute to economic and social changes and be considered one of the main inputs to generate wealth and welfare in society.

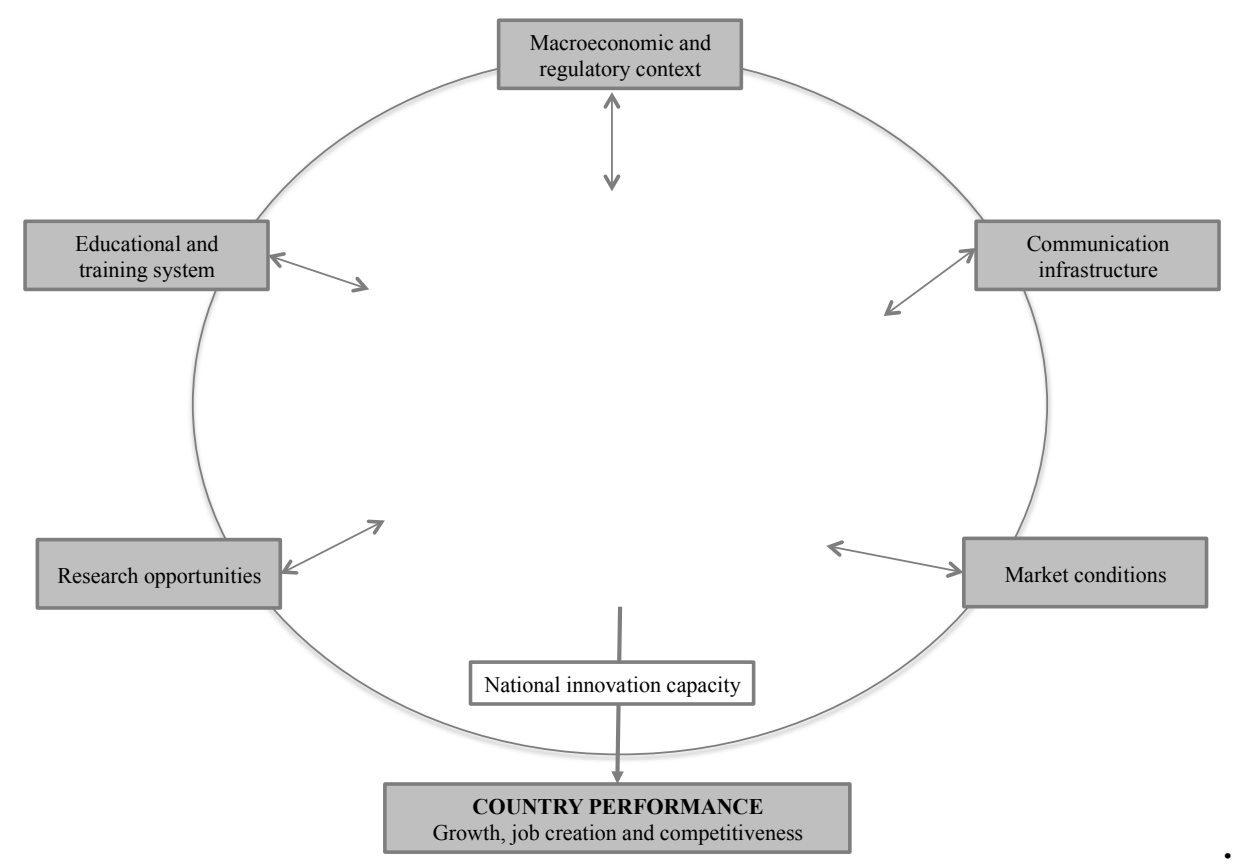

Figure 1. Innovation System Structure (based on Viotti, 2003)

Figure 1 shows the interactions between actors involved in the interactive processes of knowledge creation, dissemination and application and highlights the important role of government to support and regulate innovative activities. Private organizations are not able to innovate without direct or indirect collaboration of a group of agents and public and private institutions that offer infrastructure, establish standards and provide other essential services to their innovation process (OECD, 2004). Furthermore, innovation process is influenced by organizational, economic and institutional factors and seeks to capture the influence of the microenvironment on the technological dynamism of the system (Leydesdorff, 2013). Thus, institutional framework guides these interactions to facilitate and limit the learning process by controlling macroeconomic and regulatory context, communication infrastructure, market conditions, educational and training system and research opportunities (Viotti, 2003).

The model presented in the figure 1 also highlights innovation process as one of the most important mechanisms for strengthening local and regional economies by contributing to increased productivity and competitiveness of enterprises. Vazquez-Barquero (2009) created a model called the "forces of development" to illustrate four mechanisms that lead capital accumulation and economic growth: i) innovation and knowledge dissemination to increase differentiated products, reduce production costs and improve economies of scale, ii) flexible organizations 
to form networks and alliances, favour internal and external economies of scale and improve competitive positioning of cities and territories; iii) urban and territorial development to create innovative and dynamic cities, and iv) institution adaptation and change to manage the complexity and density among networks and allow trust between actors and reduce transaction costs. Government and regulatory entities define innovation policies to joint action of these forces in order to create synergies between them and boost local and regional economic growth (Vazquez-Barquero, 2010).

\subsection{Innovation System in Developing Countries}

The first studies on innovation system were conducted based on the perspective of developed countries (Nelson, 2004). Then, the research evolves to focus on analyzing the reality of less developed countries and regions. From Freeman's studies (cited by Leydesdorff, 2013) on the innovation system in Japan, economists have a great interest to study this concept to identify determinants of innovation processes and its dissemination. They concluded that institutional and technological differences are one of the determinants of the level of development and inequality between countries (Acemoglou and Dell, 2009).

Buesa et al. (2002) recognize that innovation system of developed countries are deeply consolidated, but in less developed countries these systems are poorly structured and have great challenges for their consolidation. Most of these countries have low technological infrastructure, limited government spending in science and technology activities, scare expenses in research and development and shortage of human talents engaged in these activities (Lundvall et al., 2011). Therefore, they possess a week system of science and technology that is not yet effectively transformed into National Innovation System. In this context, businesses, universities, research centres and regulatory institution experience strong difficulties to exercise their innovation initiatives (Pietrobelli and Rabellotti, 2011).

The above asymmetries bring several consequences to innovation systems in less developed countries. Bessant (2005) emphasizes them in three vicious circles: i) high inequality and low innovation capacity feed each other, ii) knowledge supply in a weaker market results in scare use of knowledge, and iii) research initiatives are not totally linked to social needs. On the other hand, these vicious circles are obstacles to consolidate innovation systems because inequality hampers innovation, making it difficult to overcome inequality, limited social use of knowledge discourages generation making it difficult to expand their use and a weak academic system can't primarily serve society, making it difficult to overcome their weakness. These elements delay efforts in less developed countries to reduce these asymmetries.

Globalization has contributed to increasing economic dependence and technological divide in fewer developing countries. Globalization confronts countries with challenges whose resolution depends on their development, as their resolution depends on critical variables such as capital accumulation, technical change, foreign trade composition, growth rates, employment and distribution of wealth and income (Prasad, 2005). Indeed, new asymmetries are created when developing countries are forced to open their markets to products and services from developed countries, which don't transfer technology knowledge and don't open their market to products and services from developing countries (Wright et al., 2005). Therefore, government from developing countries should play against restrictions imposed by economic globalization, in terms of achieving good processes of technology transfer (Narula, 2014). After Wright and co-authors (2005), it's not enough to have access to information, developing economies have to assimilate knowledge and transform them into new products (goods and services), new processes and methodologies to adequately respond to specific needs of each region.

However, this transformation is not an easy for less developed countries due to lack of technical and scientific knowledge to innovate. Accessing to this knowledge, since it's not a public service, is strongly difficult to reach. Large corporations or governments in developed countries usually own knowledge. They prevent free access to knowledge as a way of ensuring their participation and competitiveness in different markets. Moreover, given interactive nature of innovation asymmetry of knowledge among suppliers of innovation and users of less developed countries can generate inadequacy of innovation (Brown and Hegel, 2005).

Given these asymmetries and diversity of innovation systems, some studies have tried to classify countries according to their level of development and technological capacity obtained by the agents and institutions that make up National Innovation System. Watkins and co-authors (2015) defined three categories to describe development level of national innovation system. In the first category are those innovation systems that give knowledge and support capacities to their agents and remain leaders of technological processes, such as the United States, Japan, Germany, England, France and Italy. In the second category, there are countries that have a high technological dynamism, and innovation systems that are able to absorb and disseminate technologies produced by technologically advanced 
countries. These countries are divided into two groups: one consisting of the "small high-income" countries like Sweden, Denmark, Switzerland and the Netherlands and the other formed by the Asian countries like South Korea and Taiwan. In the third category, there are peripheral or less industrialized countries whose science and technological system are not yet transformed into innovation systems. These countries are Brazil, India, Mexico and Argentina.

To limit innovation asymmetries and enable strong innovation systems in developing countries, it is necessary to establish state policies in $\mathrm{t}$ short, medium and long term to strengthen the chain established between education, basic and applied science, technology and innovation. It also requires companies encourage the use of information technology, innovation and technological development in their products and services. Policies should promote the formation and development of human capital as a determinant for the incorporation of knowledge into production processes, promote the improvement and increase of financing programs for scientific and technological development and innovation and protect intellectual property rights. However, enabling this environment is complex because it requires participation of various actors, which easily leads to coordination problems and there are market failures that often generate private investment in less innovation. Therefore, Government intervention should be focused on solving market failures, described in the table 1.

Table 1. Markets Failures in Innovation Systems

\begin{tabular}{|c|c|}
\hline Market failure & Description \\
\hline Externalities & $\begin{array}{l}\text { The innovative process and its products generate social benefits that are not considered } \\
\text { when innovation is planning privately. There are innovative projects that are not } \\
\text { profitable privately, but that might be socially profitable. }\end{array}$ \\
\hline Public goods & $\begin{array}{l}\text { When knowledge is socialized, it becomes a public good. Therefore, it is difficult to } \\
\text { prevent others from using innovations generated by a company; this still occurs even } \\
\text { in systems that protect intellectual property rights. }\end{array}$ \\
\hline Information asymmetry & $\begin{array}{l}\text { Since equal access to information is limited, companies that invest in innovation can } \\
\text { be perceived as riskier by the financial system, resulting in fewer opportunities to } \\
\text { funding innovation projects. }\end{array}$ \\
\hline Coordination problems & $\begin{array}{l}\text { Companies don't innovate on their own; however there are obstacles for companies to } \\
\text { cooperate with each other or with academic institutions. }\end{array}$ \\
\hline
\end{tabular}

\subsection{Innovation System Configuration}

In addition to macroeconomic conditions, innovation process involves other determinants as i) a regulatory framework (Dufur, 2004), ii) an institutional environment (Harwrave et al., 2006) and iii) culture of co-operation (Fornhal and Brenner, 2003). These three elements characterize the environment in which institutions and companies are located and regulate production activities, product marketing, technological capacity, acquisition of new goods and services, development of innovative and learning activities and the formation of human capital.

According to the concept of innovation system defined by Carayannis and Campbell (2012), the regulatory framework, institutional environment and culture of co-operation assume specific roles in the process of production and transmission of knowledge. Furthermore, innovation systems are also characterized by the quality and quantity of interactions between these elements and their environments; therefore, it's essential to establish a more open and comprehensive understanding links between them, integrating environmental issues, such as technical, economic, political, social and cultural factors (Geels, 2005). Thus, innovation system performance depends not only on companies and organizations initiative teaching and research, but also how agents in the environment interplay each other respecting the legal framework, institutional environment and culture.

To establish the above elements, innovation system should employ some mechanisms that will encourage further interaction and co-operation between the agents. These mechanisms are:

i) Structural interface - a unit in a defined geographical area that encourages agents to innovate and frames relationships between them. The purpose of this structure is to offer and make available information, disseminate and advise agents in the innovation system. To frame co-operation between actors, the 
structure should be formed by four different settings that should support innovation activities (Geels, 2005). These settings are classified according to the main activities carried out by its elements (agents) in the innovation process. Fernandez and co-authors (2007) defined the following settings: scientific setting - formed by scientific organizations and research centres that perform the production of scientific, technological and innovation knowledge - technological and advanced service setting - formed by organizations that develop technologies and provide specialized technical services - productive setting formed by companies that produce goods and services - and financial setting - formed by organizations and agents offering financial resources to fund innovation projects and innovative activities of operators in other environments.

Instruments to promoting interrelationships - incentives or subsidies that aims to encourage development of innovation activities and more durable co-operation between agents. This instrument frame environment to offer adequate legal, cultural, institutional and political conditions to agents.

\section{Methodology}

Aerospace sectors in the world generates over $\$ 450$ billion USD and is a source of skilled jobs, as well as a source of activities closely linked to the development of new technologies (AeroStrategy, 2009). This sector contributes to detonating innovation activity and generate greater added value along of its production chain. These characteristics make aerospace sector a highly attractive industry for developing economies such Brazil and Mexico. These two countries have created an innovation system around aerospace to make them part of this global chain, increase their share in this sector, attract national and international investment, generate more value-added engineering activities and eventually detonate research and development project that allows them to grow their economies.

\subsection{Research Strategy}

This paper aims to draw and analyze the national innovation structure present on the Brazilian and Mexican aerospace sector. It was possible to achieve it by using the exploratory research with descriptive amplitude. According to Mattar (2001), the exploratory research is useful when the problem is not clear to the researcher, who wants to grab more knowledge about the subject. Gil (2002) states that the goal of the descriptive research is to describe the characteristics of a population or a phenomenon and to establish relations between the variables.

Moreover, it is a double case study because according to Yin (2014), the case study is used to investigate a contemporary phenomenon in its real-world context, especially when the borders between phenomenon and context are not evident. Another reason for choosing this method is the empirical research having as a source of information the environment where these changes took place and the actors involved (Yin, 2014). The qualitative and quantitative approach is also applicable, as the perspectives of the involved actors in the problematic are relevant to understand the causal relations (Ellinger, 2005).

We carried out a content analysis based on public information presenting characteristics of Brazilian and Mexican aerospace industry. We identified several documents such as research papers (40 analyzed documents), academic documents (24 analyzed documents), white papers (16 analyzed documents), industrial documents (86 analyzed documents) and news (110 analyzed documents). We analyzed and classified the collected data in function of settings and agents into the innovation system structure (scientific, technological and advance services, productive and financial) and mechanisms used to improve coordination between settings and to avoid market failure. Then, we took a close look to interactions between settings and agents by identifying collaboration projects. Finally, we developed a database of different actors involved in these innovation systems and their related characteristics: region, size, mission, objectives, partners, customers and projects. We analyzed the above information to better characterize the Brazilian and Mexican innovation systems.

\subsection{Case Studies}

Brazil and Mexico are the two largest economies in Latin America and together represent almost 2/3 of regional GDP. In commercial terms, they concentrate $57 \%$ of Latin American exports. They are the first and second most populous country in Latin America. Brazil is the largest country in Latin America with 8.51 million square kilometres (IBGE, 2010) and Mexico ranks third with 1.96 million square kilometres (INEGI, 2010). According to United Nations Program for Development, the Human Development Index puts Mexico in a better position with respect to Brazil (PNUD, 2010). After the Inter-American Development Bank, Mexico and Brazil economies show structural differences that lead them to experience differentiated impacts and opportunities in the world economy (see table 2). 
Table 2. Brazil and Mexico Contexts

\begin{tabular}{lll}
\hline \multicolumn{1}{c}{ Parameter } & Brazil & Mexico \\
\hline Population (million) & $\mathbf{1 2 5}$ & $\mathbf{2 0 6}$ \\
Less than 15 years (\%) & $28,6 \%$ & $23,5 \%$ \\
Between 15 and 64 years (\%) & $65,6 \%$ & $69,0 \%$ \\
65 years and more (\%) & $6,3 \%$ & $7,6 \%$ \\
Population below the poverty line (\%) & $53,2 \%$ & $7,4 \%$ \\
Gross domestic product GPD (USD trillion) & $\mathbf{1 , 2 8 ~ \$}$ & $\mathbf{2 , 3 5 ~ \$ ~}$ \\
GDP growth rate (\%) & $2,23 \%$ & $0,14 \%$ \\
GDP per Capita (USD) & $10325 \$$ & $11384 \$$ \\
Unemployment rate (\%) & $4,9 \%$ & $6,8 \%$ \\
Consumer price index CPI rate (\%) & $4,02 \%$ & $6,33 \%$ \\
External Debt (USD billion) & $236 \$$ & $152 \$$ \\
Trade \% of GDP & $\mathbf{6 5 , 8 6 \%}$ & $\mathbf{2 5 , 7 9 \%}$ \\
Imports of Goods \& Services \% of GDP & $33,46 \%$ & $14,27 \%$ \\
Exports of Goods \& Services \% of GDP & $32,39 \%$ & $11,52 \%$ \\
Industry*, value added \% of GDP & $34,38 \%$ & $23,41 \%$ \\
Manufacturing**, value added \% of GDP & $17,67 \%$ & $10,91 \%$ \\
Expenses for R\&D (USD billion) & $10,60 \$$ & $18,20 \$$ \\
\hline
\end{tabular}

*Industry corresponds to ISIC divisions 10-45 and includes manufacturing (ISIC divisions 15-37). It comprises value added in mining, manufacturing (also reported as a separate subgroup), construction, electricity, water, and gas.

**Manufacturing refers to industries belonging to ISIC divisions 15-37. Value added is the net output of a sector after adding up all outputs and subtracting intermediate inputs. It is calculated without making deductions for depreciation of fabricated assets or depletion and degradation of natural resources.

Source: OCDE I-Library, 2016

Brazil is characterized as a net exporter of commodities having significant commercial exchanges of goods and services to emerging markets and low dependence on demand and remittances from industrialized countries. However, despite the importance of exports in this entire model, the Brazilian economy has experienced a decline in exports and a strong expansion of private consumption and investment. This has brought an important change in the sources of growth. While between 2003 and 2007 exports were the engine, now it is the turn of domestic demand: consumption, investment and government spending (IADB, 2011). Thus, the Brazilian economy presents a relatively new export context that Mexican trade: exports account for 11, 52\% of GDP (51\% of which went to industrialized countries in 2007). Brazil has an economy that depends on the production of grain, citrus, oil and metals, which generate lower value added manufacturing and subject to volatile international prices. In addition, Brazil is experiencing a political crisis and a severe recession that limit its growth.

Mexican economy experiences interesting growth and political stability. The unemployment rate in Mexico in 2015 was 3.7\%, according to the National Institute of Statistics and Geography (INEGI). Mexico's economy grew 3,5\% in 2015. Mexico has a diversified economy with increasingly robust and differentiated thanks to trade agreements with over 40 countries, highlighting the treaty in North America with US and Canadian manufacturing. Mexico has stronger business links in goods and services with industrial countries: it's mainly commodity importers and has a high dependence on remittances from industrial countries. Mexico is more open than Brazil, its exports account for $33,36 \%$ of GDP and show greater dependence on demand from industrial countries (IADB 2011). In addition, Mexico has an ambitious agenda of reforms undertaken. This transformation allows important source of national and international investments, which represent a larger share of the Mexican economy compared to Brazil. After IADB, Mexico maintains a high level of consumer and investor confidence (IADB, 2011).

\subsubsection{Brazilian Aerospace Industry}

According to the report provided by CUT (2012), in 2012, the Brazilian aerospace industry employed 26,232 workers, distributed across 60 cities of 16 states. Only 57\% of them hold a high school degree. Considering all 
employees, $74.4 \%$ of them work for large companies, $11.3 \%$ for medium-sized companies and $14.3 \%$ for small or micro enterprises. In 2008, best year for sales, the Brazilian aerospace sector registered a trade surplus higher than \$ 1 billion USD.

Among all aerospace manufacturers operating in Brazil, two of them stand out: Embraer and Helibras. These companies work in different market niches. Embraer commercializes fixed-wing aircraft and Helibras commercializes rotor crafts, both acting in civil and military markets.

In 1969 Embraer (Empresa Brasileira de Aeronáutica S.A.) was born in São José dos Campos-SP, fulfilling an old national project of developing its own aviation industry (Forjaz, 2005). In the fourth quarter of 2008, Embraer has demonstrated its economic power showing a net income close to \$ 4 billion USD. According to Embraer (2012), the company estimates to sell about 6,800 commercial jets until 2031, which represents a value around $\$ 315$ billion USD.

Helibras, a subsidiary of Airbus Helicopters Group, is the only helicopter assembler of Latin America and responsible for $50 \%$ of all helicopters operating in Brazil. It was also founded in São José dos Campos-SP, in 1978, however, in 1980, was transferred to Itajubá-MG, where it currently remains. Nowadays, Helibras is responsible for assembling fifty EC 725 helicopters to the three Brazilian armed forces: army, navy and air force. The contract is valued at $\$ 2.45$ billion USD (Laux, 2013).

\subsubsection{Mexican Aerospace Industry}

Mexican aerospace sector has growth almost 20 percent annually over the past seven years and reached around 7,1 billion in 2013, accounting for around $0.6 \%$ of the total global value in the A\&D industry (PwC, 2015). Mexican aerospace sector is the fourth largest in the Americas, after the US, Canada and Brazil. The civil aerospace segment is the most lucrative segment, accounting for $65.1 \%$ of the total market value (SE, 2015). There are currently 249 companies and support organizations in the country, the majority of which have been certified by NADCAP and AS910 (PwC, 2015). They are mainly distributed in six states and employ more than 31,000 high-level professionals. Among all aerospace manufacturers operating in Mexico, four of them stand out: Bombardier, Safran Group, General Electric (GE) and Honeywell Eurocopter (SE, 2015).

The exportation of Mexican aerospace industry has been increasing from 2010 to 2014, reaching $\$ 1,054$ million USD in 2014, which also took around $0.3 \%$ of the total exportation that year (PwC, 2015). The importation of the Mexican aerospace industry experienced some variation. In 2014,the importation reached \$ 413 million USD, 0.1\% of the total importation. Mexico is in 10th place as a supplier of aerospace components to the United States and in turn is in 5th place as the largest supplier to the European Union (SE, 2015). According to estimates of the Pro-Aeréo 2012 - 2020 coordinated by the Ministry of Economy, it is expected to export 12 billion in 2021, with an average annual growth of 14 percent (Environmental Performance Reviews, 2013).

Mexican government is investing in creating talent for this sector and establishing research centres or institutions to serve the industry and enhance its current situation. Mexican government has carried out the Pro-Aeréo $2012-2020$ to guide the industry, aiming to place Mexico among the top 10 suppliers in aerospace industry worldwide (SE, 2015). This plan will lead development of three aerospace sectors: manufacturing, engineering/design and maintenance, overhaul and repair.

\section{Results}

\subsection{Brazilian Innovation System}

The aerospace industry structure commonly follows a hierarchical pyramid, where the final assemblers, or builders, are on the top of the pyramid, straight followed by the first-tier suppliers, who sell large systems. Second-tier suppliers support first-tier suppliers and so on. Generally, small and medium-sized companies operate on the third and fourth tier (Hum, 2012). These companies participate in different market segments and manufacture a wide range of products and manufacturing tools. The providers, beside of being part of large companies supply chain, are often part of an established innovation system, as well as universities and agencies. Figure 2 shows the hierarchical structure of the aerospace sector. 


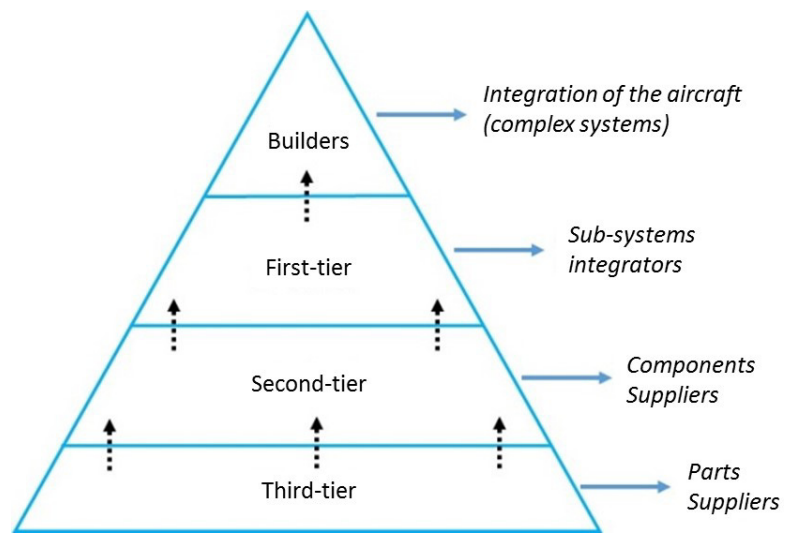

Figure 2. Hierarchy of the Brazilian Aerospace Industry

Source: Adapted from Ferreira \& Sabbatini (2013).

It was verified that Helibras shares about $33 \%$ of all its suppliers with Embraer. As well as integrating both supply chains, some of these suppliers also participate in joint development of new technologies. It applies to AEL Systems A.S., AKAER and Rockwell Systems. Another important data is that about 35\% of all companies present in both supply chains work with metallic and composite structures for aircraft and $40 \%$ of all companies have evident environmental policies on their websites.

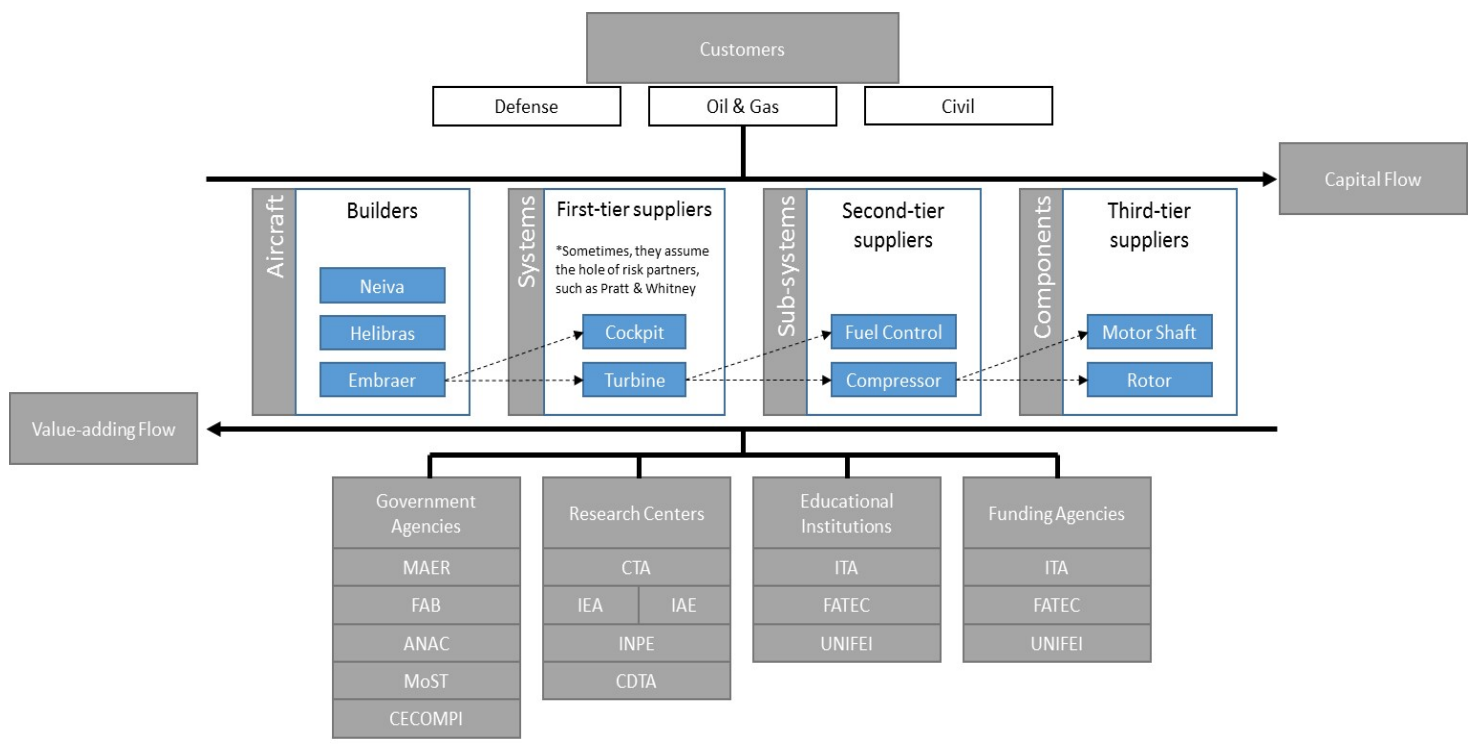

Figure 3. Brazilian Aerospace Industry Supply Chain and Additional Organizations

The socio-economic region of São José dos Campos is the Brazilian region where most of industries and institutions linked to the aerospace sector are. It is not only because of Embraer, but also due to the presence of the Aeronautics Institute of Technology (ITA) and the National Institute for Aerospace Research (INPE). Nowadays, there are over 130 companies integrating the conglomerate, such as Ambra Solutions, A.S., Avionics Services, BrasCopter, Giovani Passarella, Friuli, Finetornos, Flight Solutions, Flight Technologies, Globo Usinagem, Winnstal and InbraAerospace. Most of these companies are Brazilians and integrate the supply chain of Embraer and other large foreign companies with branches in the region, such as Latecoere (French), Aeronova and Gamesa (Spanish), Pilkington Aerospace (British) and Sobraer (Belgian). Figure 3 shows the supply chain for the Brazilian aerospace sector and brings some examples of institutions that contribute to the national innovation system. 


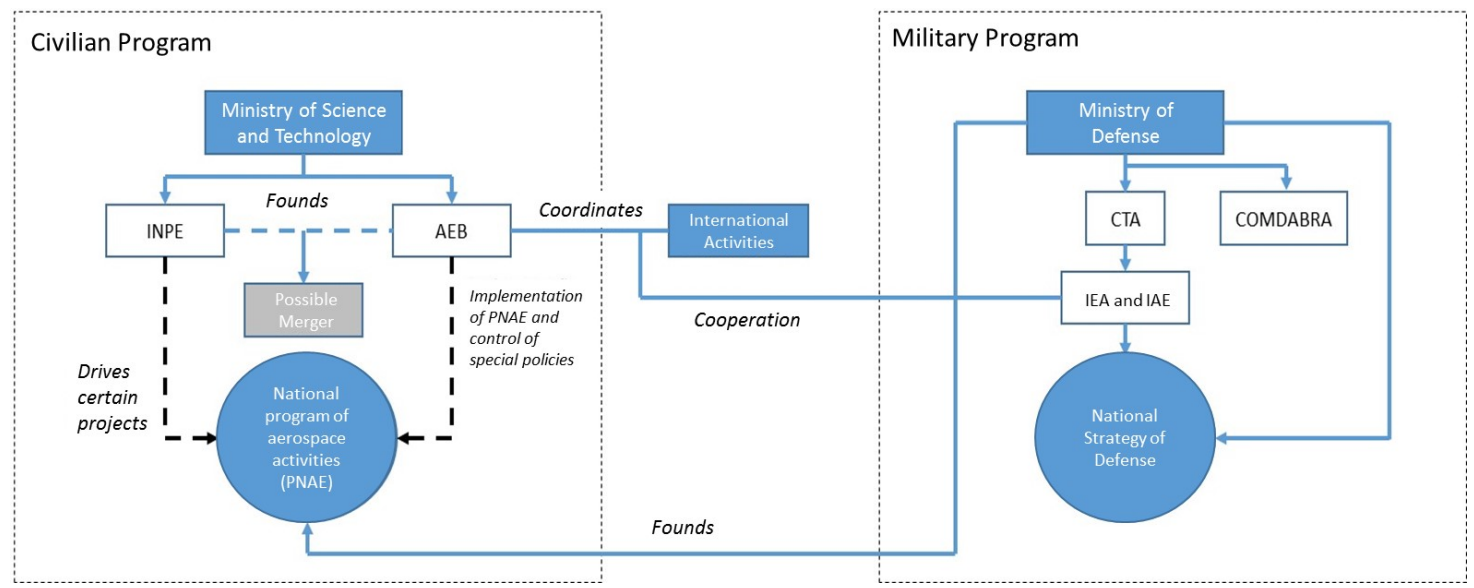

Figure 4. Structure and Governance of the Brazilian Aerospace Program

Source: Adapted from Euroconsult (2012)

Considering the Brazilian system of innovation in the aerospace sector, many institutions stand out: the Brazilian Space Agency (AEB), responsible for implementing aerospace programs; the National Institute of Space Researches (INPE) that investigates new technologies; the Aerospace Technical Centre (CTA), formed by several institutes, such as the Institute of Aeronautics and Space (IAE) and the Institute of Advanced Studies (IEA). The Brazilian Aerospace Defence Command (COMDABRA) is responsible for the integration of monitoring capabilities and some government agencies, such as the Brazilian Air Force (FAB), responsible for many military projects, and the National Agency of Civilian Aviation (ANAC), which makes the rules and requirements for civilian aircraft. Figure 4 shows the structure and governance of the Brazilian space program (Euroconsult, 2012).

Analyzing the figure 4 above, two types of programs stand out: the civilian and the military. The civilian program is sponsored by the Ministry of Science and Technology, which provides found to INPE and AEB, both responsible for investigating new technologies. On the other hand, considering the military program, it is up to CTA, throughout specific institutes such as IEA and IAR, investigate and develop projects and new technologies, always in agreement with requirements imposed by the Ministry of Defence. The ministries provide founds that sometimes are leveraged by founding agencies, such as the National Bank for Social and Economic Development (BNDES), the Financing of Studies and Projects (FINEP) and some specific programs, like the Exportation Financing Program (PROEX). Considering the Brazilian Aerospace Program, founds can be provided by the Ministry of Defence or Ministry of Science and Technology, depending on the expected end to the developed technology.

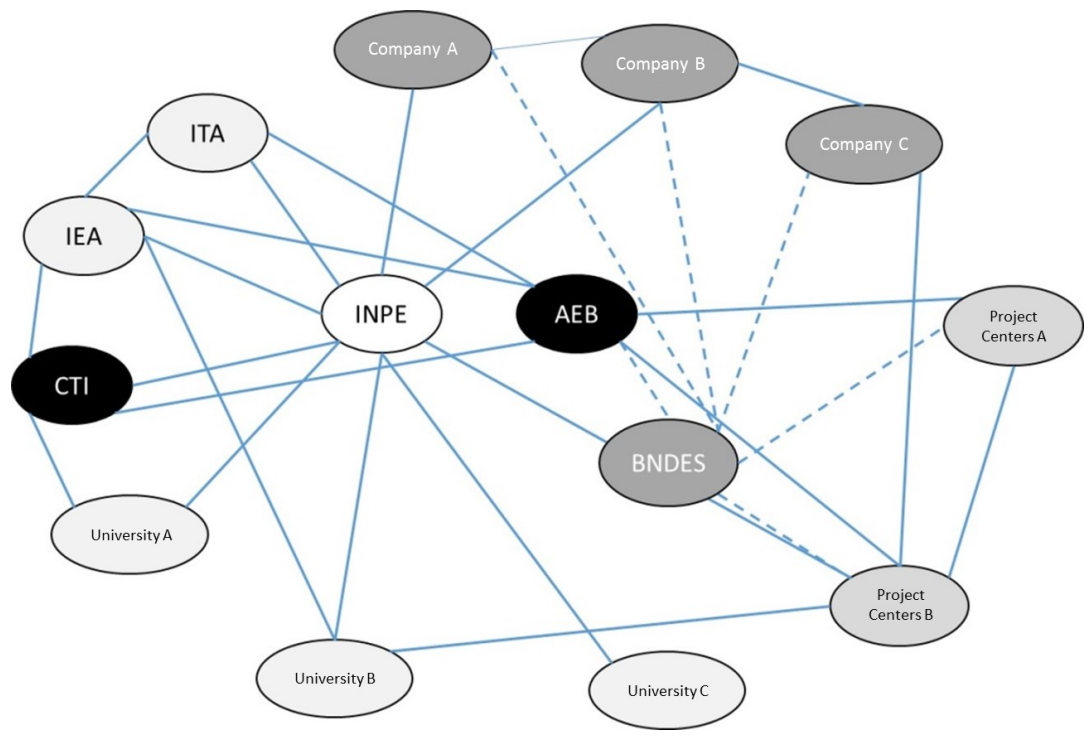

Figure 5. Cluster of the Brazilian Innovation System

Source: Adapted from Fernandes et al. (2011) 
Structuring all organization in the form of web and placing innovation at the heart of the study is generated the Figure 5, adapted from a Harvard study about the Brazilian civil aviation (Fernandes et al., 2011).

The figure 5 highlights the main institutions involved in the Brazilian innovation system for the aerospace sector. In this case, INPE figures as the main articulator of the system, which communicates with almost all organizations in many levels. BNDES appears as the main founding organization, interacting with all companies and research centres.

\subsection{Mexican Innovation System}

From its economic crisis in 1994, Mexico has redefined its development model and followed closely Washington Consensus recommendations regarding structural reforms for oriented markets. Mexico has fundamentally liberated capital flows, privatized public enterprises, reduced considerable barriers to trade and foreign investment, changed subsidy schemes, reoriented macroeconomic policy towards controlling inflation and signed free-trade agreements. This transformation allowed developing an innovation system focus on the automotive sector for supporting manufacturing activities, as result Mexico is nowadays recognized by its great experience and knowledge in manufacturing.

Aerospace innovation system in Mexico is made up of 248 companies and support organization: $70.6 \%$ engaged in manufacturing, $16.9 \%$ in engineering and design and $12,5 \%$ in the maintenance overhaul and repair (SE, 2015). These agents are mainly distributed in 6 states employing more than 31,000 high-level professionals. However, coordination mechanism as funding and policies are expanding this regional system to north and central Mexico. Table 3 shows states having aerospace initiatives: universities and research centres with aerospace projects and organizations classified by the type of activities: M (Manufacturing), MRO (Maintenance, Repair and Overhaul) and R\&D (Engineering and Design).

Table 3. National Innovation System in Mexico

\begin{tabular}{|c|c|c|c|c|c|c|}
\hline \multirow{2}{*}{ States } & \multicolumn{4}{|c|}{ Organizations } & \multirow{2}{*}{$\begin{array}{c}\text { Teaching and } \\
\text { research }\end{array}$} & \multirow{2}{*}{ Tota } \\
\hline & $\mathbf{M}$ & MRO & R\&D & Total & & \\
\hline Aguascalientes & 1 & 2 & - & 1 & 2 & 3 \\
\hline Baja California & 41 & 5 & 5 & 50 & 5 & 55 \\
\hline Chihuahua & 25 & 2 & 1 & 27 & 2 & 29 \\
\hline Coahuila & 3 & 1 & - & 5 & 1 & 6 \\
\hline Mexico city & - & 4 & 1 & 4 & 4 & 8 \\
\hline Estado de Mexico & 1 & 2 & - & 2 & 2 & 4 \\
\hline Guanajuato & 1 & 2 & 1 & 3 & 2 & 5 \\
\hline Hidalgo & - & 0 & - & 1 & 0 & 1 \\
\hline Nuevo Leon & 12 & 5 & 1 & 18 & 5 & 23 \\
\hline Jalisco & 8 & 1 & - & 8 & 1 & 9 \\
\hline Puebla & 2 & 2 & 1 & 3 & 2 & 5 \\
\hline Queretaro & 23 & 7 & 4 & 31 & 7 & 38 \\
\hline San Luis Potosi & 3 & 1 & - & 3 & 1 & 4 \\
\hline Sonora & 37 & 3 & 3 & 40 & 3 & 43 \\
\hline Tamaulipas & 9 & 1 & - & 9 & 1 & 10 \\
\hline Yucatan & 2 & 1 & - & 2 & 1 & 3 \\
\hline Zacatecas & 1 & 1 & - & 1 & 1 & 2 \\
\hline Total & 169 & 40 & 17 & 208 & 40 & 248 \\
\hline
\end{tabular}

Mexican government has taken advantage of its strong manufacturing capacities to launch its aerospace innovation system. Indeed, manufacturing is an important factor that favours aerospace sector in Mexico. Among the main manufactured products are harnesses, machined parts, safety equipment and fuselage assemblages for aircraft and helicopters. Another key factor that supports aerospace innovation system in Mexico is MRO activities. MRO 
services that are performed worldwide, representing \$ 44 billion USD per year, equivalent to $35 \%$ of sales in the aeronautical sector (Oliver Wyman, 2015). It is estimated that the total expenditure for 2018 will be $\$ 55$ billion USD (Oliver Wyman, 2015).

In the Mexican aerospace innovation system, it is possible to find most of agents identified in what authors might call 'Innovation Systems that work well'. However, there are some failures to coordinate knowledge transfer and interactive learning. These failures do not allow better interaction between the system agents. The most important agents of SMI are: government agencies and institutions, institutions of higher education, centres and public research institutes, companies and financial sector.

Mexican government is the main regulating agent system as he defines and modifies the regulatory regime, the macro policies and contributes to funding. The National Council of Science and Technology (CONACYT) is the main state institution to design, implement and coordination innovation systems. CONACYT has made many contributions to consolidate aerospace innovation system. It has created a large network of public research centres and build five state universities, which cover 31 states. In addition, this council support well-qualified workforce and training of high-level scientists by granting scholarships.

Universities, technology institutes, state educational institutions and colleges compose Mexican System of Higher Education Institutions (IES). Universities are the most visible innovation system agent, as are the main centres for training of highly qualified personnel and production of basic science and applied science, with potential to be used for productive purposes and innovation. The annual budgets of public universities rely primarily on resources provided by the Government and generally show little willingness or ability to bond with the productive sector. Therefore universities are limited to generate levels of self-financing that allow them to rely less on public funds.

Actual research projects permit to strengthen manufacturing and MRO capacities of Mexican agents. In Mexico, there are three main private centres for innovation and research.

- Honeywell Aerospace Research and Technology Centre: This centre has 370 employees of whom 75\% have engineering skills. They are distributed in four units: a design centre, a laboratory for system integration, an annex for engineering tests and a group of business support. This centre performs manufacturing, design and testing of aircraft engines and mechanical generators. Among its clients is Airbus.

- General Electric Infrastructure Queretaro (GEIQ): inaugurated in 1999 in Queretaro, this centre is the largest GE Aviation engineering centre and the second of GE Energy outside United States with more than 1,300 engineer jobs. This centre is dedicated to design aircraft and power generation turbines.

- ITP Engineering and Manufacturing, S.A. de C.V: was opened in 1998 in Queretaro as the result of the alliance between Aeromexico the Spanish company Industria de Turbo Propellers. ITP is dedicated to engineering, research and development, manufacturing and foundries, assembly and testing of aeronautical engines and gas turbines. Furthermore, it also develops MRO capacities for Pratt \& Whitney and Honeywell products.

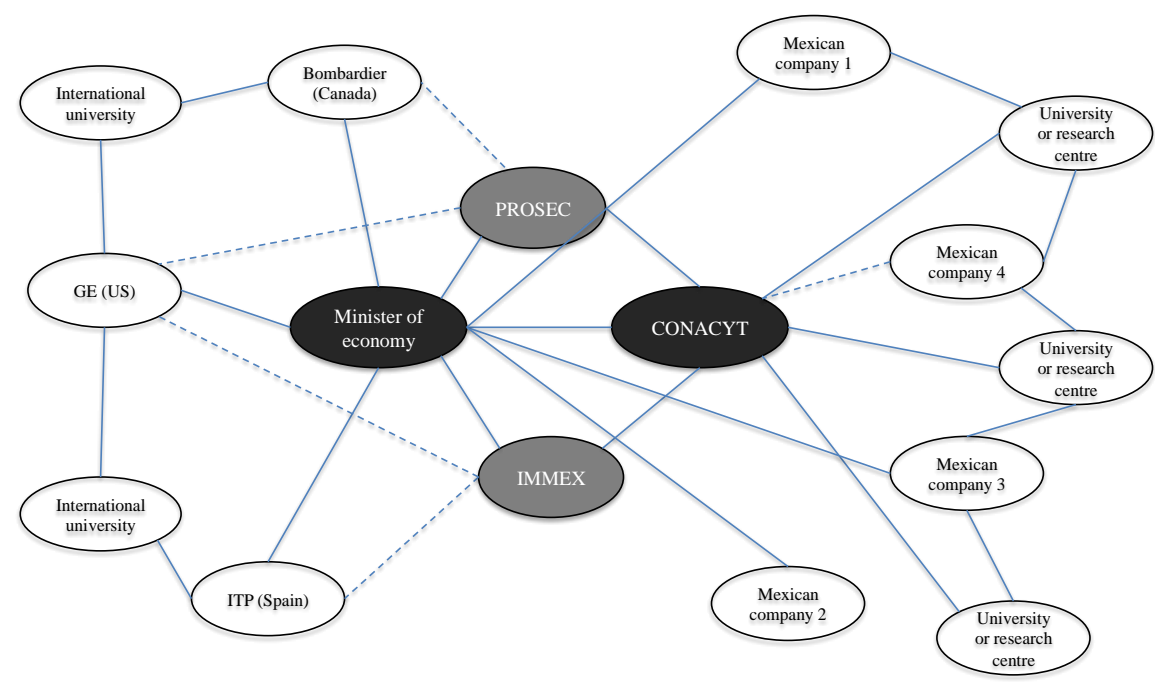

Figure 6. Cluster of the Mexican Innovation System 
Structuring all organization in the form of web and placing innovation at the heart of the study is generated the Figure 6. Aerospace innovation system is structured in two main components: international capital system (left side of Figure 6) and national capital (right side of Figure 6). The international system has limited interaction with Mexican innovation system; their bridge with the national system is the Minister of economy. On the other hand, businesses in the national capital system maintain links between technology and regulatory entities (CONACYT, PROSEC and IMMEX), as well as local universities and research centres. However, co-operation between Mexican organizations is limited.

Aerospace innovation system in Mexico has adopted a mechanism to support external commerce. Companies established in Mexico to assembly or manufacture aircraft parts, as well as companies that perform MRO, have preferential access to imported inputs, parts, components, machinery, equipment and other goods related to its production activities, enabling them to have flexible and competitive procurement, exempt from duty. As part of the foreign trade mechanisms that support industrial manufacturing, aerospace innovation system has traditional instruments such as the Program for Industry Promotion (PROSEC) and the program for Maquiladora Export Industry (IMMEX).

\section{Discussion}

According to the classical conception of Innovation System, it has shown that companies are at the core of the system, because they represent the only agent that can introduce new products or processes. Companies do not innovate in isolation but they articulate a network of agents that contribute to the process, providing expertise and resources of different types. However, in the Brazilian and Mexican innovation system, agents don't benefit from interactive learning for knowledge production and development of innovations. Mexican and Brazilian companies seem to have found other means of survival and growth more effective than active interaction with the other actors of the innovation system, so its innovative activity has been quite limited. Therefore, Brazilian and Mexican innovation systems haven't overcome coordination failure in the market.

Intermediate linkage, also called bridging organizations, are public and private organizations, which act as a liaison between two or more agents in the system. A very important field of action of these organizations is promoting linkages to transfer scientific and applied knowledge from universities to the business sector. However, these institutions are poorly developed in Mexico and Brazil. According to the INEGI survey (2012), only 40\% of companies consider universities as an important source of knowledge for innovation. In the case of international capital companies, they collaborated with some universities and research centres but in most of the cases, they prefer to establish linked with American, Canadian and European universities.

Aerospace innovation systems in Brazil and Mexico have adopted policies to support innovation in the region: a) forming human resources, b) increase investment in research and development (R \& D), c) strengthen existing players and widespread technological modernization, d) generating capabilities in new technological paradigms such as information technology and communication; and e) strengthen institutional capacities for the design, implementation and evaluation of policies. These are necessary steps to develop innovation activities and create the conditions for progress in strengthening innovation systems of these countries. But a reasonable provision of resources to finance such developments is needed for such measures. Such resources could be subject to a financing line in partnership with the Inter-American Development Bank.

In Brazil, the aerospace industry follows a pyramidal structure, where builders are on the top and parts suppliers are on the base. Seeking to reduce their costs and improve their processes, these companies are often part of clusters, such as the one of São José dos Campos, with about 130 industries. The Aeronautics Institute of Technology (ITA) and the National Institute for Aerospace Research (INPE) are also located in São José dos Campos, both supplying the cluster with specialized manpower, ensuring the cluster functioning. The mutual help is not restricted to the purchase and sale of goods. Conglomerate companies also cooperate in search and creation of improvements, through an established innovation system. Since Helibras shares about 33\% of its suppliers with Embraer, the two biggest aeronautic companies in Brazil, and some of them are part of the innovation system, it is noticeable that there are benefits for both of them in the search for technological improvements. However, these benefits can be observed in isolated geographical areas since the Brazilian innovation system is concentrated São José dos Campos region.

In Mexico, there are two different aerospace systems: international capital network and national network. International capital system invests in manufacturing and innovation activities but its linkages are concentrated in the central area of Mexico (Queretaro and Guanajuato). The national capital network is distributed in 17 states (north, 
central and south); however, most of agents in this network aim at activities where internal innovation efforts do not constitute important part of the competitive strategy. This statement is based on data, such as low resources for R\&D, lack of infrastructure, human resources devoted to $R \& D$ and application engineering firms. It is also reflected in the introduction of a few new or improved products and processes. Many of aerospace companies still base their competitiveness in technological capabilities built essentially for the model of import substitution industrialization, and non-technological innovations. Indeed, radical innovations in product and process developed by Mexican companies are very small. Aerospace actors act as a single agent within the system. They do not show strengths in linking capabilities with other agents. There are few partnerships, limited introduction of new products or processes based on the relationship universities and Mexican centres.

\section{Conclusions}

This paper analyzed the structure of the Brazilian and Mexican innovation system presented by the aerospace sector. Even if both countries are two emergent economies, there are major differences between them. Brazil has developed an innovation system focus on creating innovation and growth economy in São José dos Campos area. Whereas, Mexican innovation system is divided into two types of networks: international capital system that invests in innovation, but actors are concentrated in two states in Mexico, and national capital system that is distributed in north, central and south of Mexico, but agents only invest in manufacturing activities. Both countries experience difficulties to coordinate agents in their innovation systems to create or transfer knowledge. Companies have not shown great interest in participating in activities to develop their own technologies, nor are interested in expanding their internal research and development, nor to establish links with universities and research centres to innovate their products and processes.

Thus, this paper aims to expand the view of the structure of the Brazilian and Mexican aerospace innovation system beyond its performance. For future papers and investigations, the authors expect to track the development of a new project, showing all the steps taken and providing more detailed information about the structure of the innovation system.

\section{References}

Aboites, J., \& Corona, J. M. (2011). Economía de la Innovación y Desarrollo. Universidad Autónoma Metropolitana/ Siglo XXI Editores.

Acemoglu, D., \& Dell, M. (2009). Beyond Neoclassical Growth: Technology, Human Capital, Institutions and Within-Country Differences. American Economic Journal: Macroeconomics, 2, 169-188.

Aerostrategy. (2009). Aerospace Globalization 2.0: Implications for Canada's Aerospace Industry, Discussion paper. Consulted from: http://www.aiac.ca/uploadedFiles/Resources_and_Publica tions/ReferenceDocuments/The $\% 20$ Implications $\% 20$ Of $\% 20$ Globalization $\% 202 \% 200 \% 20$ For $\% 20$ Canadian $\% 20$ Aerospace(2).pdf

Belussi, F., Sammarra, A., \& Sedita, S. R. (2010). Learning at the boundaries in an Open Regional Innovation System. A focus on firms' innovation strategies in the Emilia Romagna life science industry. Research Policy, 39(6), 710-721.

Bessant, J. (2005). Enabling continuous and discontinuous innovation: Learning from the private sector. Public Money and Management, 25(1), 35-42.

Brown, J.S., \& Hegel, J. (2005). Innovation blowback: Disruptive management practices from Asia. The McKinsey Quarterly, 35-45.

Buesa, M. (2002). El Sistema Regional de $I+D+I$ de la Comunidad de Madrid. Instituto de Análisis Industrial y Financiero. Universidad Complutense de Madrid.

Campbell, D.F., \& Guttel, W.H. (2005). Knowledge production of firms: research networks and the" scientification" of business R\&D. International Journal of Technology Management, 31(1-2), 152-175. http://dx.doi.org/10.1504/IJTM.2005.006629

Carayannis, E. G., \& Campbell, D. F. (2012). Mode 3 knowledge production in quadruple helix innovation systems. In Mode 3 Knowledge Production in Quadruple Helix Innovation Systems (pp. 1-63). Springer New York. http://dx.doi.org/10.1007/978-1-4614-2062-0_1 
CUT (2012). A industria aeroespacial e da defesa no Brasil: diagnóstico e propostas elaboradas pelos metalúrgicos da CUT. Confederação nacional dos metalúrgicos, p. 1-51.

Doloreux, D., \& Parto, S. (2005). Regional innovation systems: Current discourse and unresolved issues. Technology in society, 27(2), 133-153. http://dx.doi.org/10.1016/j.techsoc.2005.01.002

DuFour, R.A. (2004). Voice over Internet Protocol: Ending uncertainty and promoting innovation through a regulatory framework. CommLaw Conspectus, 13, 471-490.

Ellinger, A.D., Watkins, K.E., \& Marsick, V.J. (2005). Case study research methods. Research in organizations: Foundations and methods of inquiry, 327-350.

Embraer (2012). Embraer market outlook 2012-2031 projects 6.800 jet deliveries 2 of 30 to 120 - seat segment. News Release, pg. 1-3. São José dos Campos, Brasil.

Environmental Performance Reviews (2013). Mexico Highlights. OECD

Euroconsult (2012). International overview of space governance and policies for the Canadian Aerospace Review. Aerospace Review: 63, 98-120.

Fernandes P., Moscoso V., Price A., Yoshino J., \& Zhang J. (2011). Microeconomics of competitiveness: aeronautics cluster in Brazil, microeconomics of competitiveness. Harvard Business School,

Fernández de Lucio, I., Martínez, E.C., Cegarra, F.C., \& Gutiérrez Gracia, A. (2007). Las Relaciones Universidad-Empresa: Entre la Transferencia de Resultados y el Aprendizaje Regional. Revista Espacios, 21(2).

Ferreira, M., \& Sebbatini, R. (2013). Engenharia de projetos na indústria aeronáutica brasileira. Agência brasileira de desenvolvimento industrial, 1-58.

Forjaz, M. (2005). As origens da Embraer. Tempos Social, Revista de sociologia da USP, 17(1), 281-298. http://dx.doi.org/10.1590/s0103-20702005000100012

Fornahl, D., \& Brenner, T. (2003). Cooperation, networks and institutions in regional innovation systems. University of Illinois at Urbana-Champaign's Academy for Entrepreneurial Leadership Historical Research Reference in Entrepreneurship.

Geels, F.W. (2005). Processes and patterns in transitions and system innovations: refining the co-evolutionary multi-level perspective. Technological forecasting and social change, 72(6), 681-696. http://dx.doi.org/10.1016/j.techfore.2004.08.014

Gil A.C. (2002). Como elaborar projetos de pesquisa (4th ed.). São Paulo: Atlas.

Hargrave, T.J., \& Van de Ven, A.H. (2006). A collective action model of institutional innovation. Academy of management review, 31(4), 864-888. http://dx.doi.org/10.5465/AMR.2006.22527458

Hoppe, R. (2005). Rethinking the science-policy nexus: from knowledge utilization and science technology studies to types of boundary arrangements. Poiesis \& Praxis, 3(3), 199-215. http://dx.doi.org/10.1007/s10202-005-0074-0

Hum, P. (2012). Aerospace small and medium sized enterprises financing: Management consulting Project. Aerospace Review: 23. Queen's University.

IADB (2011). Latin American registers strong export growth in 2011. Retrieved from http://www.iadb.org/en/news/news-releases/2011-12-19/latin-american-export-growth-reaches-26-in-2011,9787 .html

IBGE (2010). Instituto Brasileño de Geografia y Estadística. Consulted from: http://www.ibge.br

INEGI (2010). Instituto de Estadística, Geografia e Informática. Consulted from: http://www.inegi.gob.mx

INEGI (2012). Encuesta sobre Investigación y Desarrollo Tecnológico y Módulo sobre Actividades de Biotecnología y Nanotecnología. Retrieved from: http://www.inegi.org.mx/est/contenidos/proyectos/encuestas/establecimientos/otras/esidet_mbn/default.aspx

Laux. P. (2013). Helibras 35 anos: a saga da única fabricante de helicópteros do Brasil. Editora Convergência, 2013. Ed. 1, p. 1-112. São Paulo, Brasil.

Leydesdorff, L., \& Meyer, M. (2006). Triple Helix indicators of knowledge-based innovation systems: Introduction to the special issue. Research policy, 35(10), 1441-1449. http://dx.doi.org/10.1016/j.respol.2006.09.016 
Leydesdorff, L. (2013). Triple Helix of university-industry-government relations (pp. 1844-1851). Springer New York. http://dx.doi.org/10.1007/978-1-4614-3858-8_452

Lundvall, B., Joseph, K.J., Chaminade, C., \& Vang, J. (2011). Handbook of innovation systems and developing countries: building domestic capabilities in a global setting. Edward Elgar Publishing.

Lundvall, B.A. (2002). Innovation growth and social cohesion. The Danish Model. London: Edward Elgar Publishers. http://dx.doi.org/10.4337/9781781008348

Matter, F.N. (2001). Pesquisa de Marketing (3rd. ed.). São Paulo: Atlas.

Narula, R. (2014). Globalization and technology: Interdependence, innovation systems and industrial policy. John Wiley \& Sons.

Nelson, D. R., Adger, W. N., \& Brown, K. (2007). Adaptation to environmental change: contributions of a resilience framework. Annual review of Environment and Resources, 32(1), 395. http://dx.doi.org/10.1146/annurev.energy.32.051807.090348

Nelson, R. (2004). The challenge of building an effective innovation system for catch-up. Oxford Development Studies, 32(3), 365-374. http://dx.doi.org/10.1080/1360081042000260575

North, D.C. (2008). Para entender el proceso del cambio economico. Bogota. Editorial Norma.

OCDE (2004). Manual de Oslo. Rio de Janeiro: FINEP

OCDE (2016). OCDE Factbook. OCDE iLibrary. Retrieved from http://www.oecd-ilibrary.org/economics/oecd-factbook-2015-2016_factbook-2015-en

Pietrobelli, C., \& Rabellotti, R. (2011). Global value chains meet innovation systems: are there learning opportunities for developing countries?. World development, 39(7), 1261-1269. http://dx.doi.org/10.1016/j.worlddev.2010.05.013

PNUD (2010). Informe Regional sobre Desarrollo Humano para América Latina y el Caribe 2010. UN, Nueva York, $208 \mathrm{pp}$.

Prasad, E., Rogoff, K., Wei, S.J., \& Kose, M.A. (2005). Effects of financial globalization on developing countries: some empirical evidence (pp. 201-228). Palgrave Macmillan UK.

PwC (2015). Selected information about the Aerospace and Defence Industry in Mexico. Consulted from: https://www.pwc.com/mx/es/knowledge-center/archivo/20150604-gx-publication-aeros pace-industry.pdf

Sánchez-Hernández, J. L., Aparicio-Amador, J., \& Alonso-Santos, J. L. (2010). The shift between worlds of production as an innovative process in the wine industry in Castile and Leon (Spain). Geoforum, 41(3), 469-478. http://dx.doi.org/10.1016/j.geoforum.2009.12.004

Sbragia, R., Kruglianskas, I., \& Andreassi, T. (2004). O contexto econômico, a articulação institucional e o comportamento tecnológico recente da indústria brasileira. Globalización, ciencia y tecnología, vol. II. Organización de Estados Iberoamericanos.

Secretaría de Economía (2014). IED en el Sector Aeroespacial (1999 - 2014). Secretaría de Economía.

Uyarra, E., \& Flanagan, K. (2010). From regional systems of innovation to regions as innovation policy spaces. Environment and Planning C: Government and Policy, 28(4), 681-695. http://dx.doi.org/10.1068/c0961

Vázquez Barquero, A. (2009). Desarrollo local, una estrategia para tiempos de crisis. Universidad Autónoma de Madrid. Seminario Internacional de la Red DETE-ALC, Rafaela, Argentina.

Viotti, E.B. (2003). Fundamentos e evolução dos indicadores de CT\&I, En: Viotti, Eduardo Baumgratz y Macedo, Mariano de Matos (Orgs.): Indicadores de Ciência, Tecnologia e Inovação no Brasil. São Paulo: Editora de la UNICAMP.

Von Hippel, E. (2005). Democratizing innovation: The evolving phenomenon of user innovation. Journal für Betriebswirtschaft, 55(1), 63-78. http://dx.doi.org/10.1007/s11301-004-0002-8

Watkins, A., Papaioannou, T., Mugwagwa, J., \& Kale, D. (2015). National innovation systems and the intermediary role of industry associations in building institutional capacities for innovation in developing countries: A critical review of the literature. Research Policy, 44(8), 1407-1418. http://dx.doi.org/10.1016/j.respol.2015.05.004

Wright, M., Filatotchev, I., Hoskisson, R.E., \& Peng, M.W. (2005). Strategy research in emerging economies: Challenging the conventional wisdom. Journal of management studies, 42(1), 1-33. 
http://dx.doi.org/10.1111/j.1467-6486.2005.00487.x

Wyman O. (2015). Turning the tide a wave of new aviation technology will soon hit the mro industry. Retrieved from http:/www.oliverwyman.com/content/dam/oliverwyman/global/en/2015/apr /MRO-Survey-2015-digital.pdf

Yin, R. (2014). Estudo de caso: Planejamento e Método (5th Ed.). Bookman Editota Ltda. p. 2-170. 